\title{
Technē in Pre-Platonic Literature and its Significance to Modern Society
}

\author{
Shuang Wang, Qian Wang, Mingli Qin \\ Dalian University of Technology
}

\begin{abstract}
The reason for the double-edged sword effect of technology is that in modern system of knowledge, there has appeared a gap between technology and ethics which couldn't be found in ancient Greece. Going back to the Greek ancestor of technology - technē, will shed a light on the solution of the problems brought about by modern technology, because even before Plato whose ideas on technē have been heatedly discussed nowadays, technē has embraced an ethical dimension.
\end{abstract}

Keywords: technē, pre-plato, technology, ethics

\section{Introduction}

British sociologist Anthony Giddens says, "discontinuities" are the starting point to analyze modernity $(2000,3)$. His so-called "discontinuities" indicate that the modern social system has been essentially different from the traditional one as a result of the fact that modernity has cast people out of the original orbit of social order and a completely new society has been established, which has been dominated by science and technology to an unprecedented degree. Various technologies that have mushroomed in the late several decades, such as nano-technology, bio-technology, info-technology etc., have boosted the productivity and economic development and changed our ways of living in this world, but the undesirable effects have shown up as well. Instrumental rationality has been rather close to shrouding various ethical values, as a result of which, human beings are confronted with global environmental pollution, ecological imbalance, nuclear threat, and even terrorism, a situation described by Martin Heidegger as modern technology's having torn people, together with their roots out of the land. This de-rooting is rooted in the rupture among modern knowledge systems and to be more exact, the gaps between technology and ethical values. Professor Lin Dehong says, "The essence of modern technological crisis is the crisis of values and ethics and it's also the crisis of all human beings" (1999, 511). Therefore, it's high time that we should question the possibilities to end the conflicts between technology and ethical values so as to make them in peace with each other in modern society. Friedrich Nietzsche gives a

Shuang Wang, Ph.D. candidate of Department of Philosophy, lecturer of School of Foreign Languages, Faculty of School of Humanities and Social Science, Dalian University of Technology, China; main research fields: Western Literature and Philosophy of Technology. Email: wsdawn2000@163.com.

Qian Wang, Ph.D., professor of Department of Philosophy, Faculty of School of Humanities and Social Science, Dalian University of Technology, China; main research field: Philosophy of Technology. Email: qianwang@dlut.edu.cn.

Mingli Qin, Ph.D., professor of Department of English, School of Foreign Languages, Dalian University of Technology, China; main research field: Western Literature and Philosophy. Email: mlqin@dlut.edu.cn.

The project was supported by the Fundamental Research Funds for the Central Universities, DUT14RW128 and Social Sciences Fund of Liaoning Province, L14DWW012. 
hint as to how this can be done by saying that human beings feel homeless wherever they are and that consequently look back at the only place that can make them feel at home - the Greek world, because it's the only place where they hope to feel at home (Bambach 2007, 90). Therefore, in order to mend the relationship between technology and ethics, we need to go back to technology's Greek ancestor-technē.

The importance of this word could be easily found in the fact that the journal of The Society for Philosophy and Technology (SPT) is named after it. Scholars who have written on this concept mostly focus their attention on Plato's dialogues to either establish or dissolve the relationship between technē and virtue. However, one point they seem to have overlooked is that far before Plato, technē has been interwoven with something ethical although ethics hasn't been established as a discipline yet at that moment. Therefore, in order to avoid being anachronistic, when the paper uses "ethics" and "ethical" to refer to something in the texts before Plato, the idea but not the discipline is concerned.

\section{The Concepts of Ethics and Technē}

The central idea of this paper is that in pre-platonic writers, ethics and technē are united and therefore the two concepts need to be defined etymologically before the revelation of their original relationship.

The reason why "ethics" is preferred to "moral" or "virtue" in this paper is that according to Hegel, the latter refers to individual disposition, more subjective-oriented while the former is objective (Hegel 1961, 42-43). It's well known that philosophers before Socrates are devoted to the study of nature and it is Socrates that who, replacing the subject matter of philosophical study with human affairs, takes "good" as the target of philosophical inquiry. Ethics is the universal contemplation about all moral phenomena in a society, and that's the reason why ethics is considered as moral philosophy. A historical and cultural perspective should be adopted in order to take an accurate grasp of this concept. It comes from the ancient Greek "ethǒs," which means the place inhabited by a community in Homer epics. And later it gradually embraced the meaning of humans' disposition, traditions, and habits. The first person who considers ethics as a scientific study is Aristotle who modifies the word ethǒs a little to associate it with the judgment about good and evil and establishes ethika to answer such questions as "how should one live?" or "how should one act?" in order to achieve eudaimonia, the Greek word for flourishing or happiness. It is different from pleasure, which is transient and temporary, since "eudaimonia concerns the shape of one's whole life rather than particular moments or parts of one's life" (Bunnin \& Yu 2001, 336). Chinese equivalent of "ethics" is "Lunli." "Lun" means status of a generation in a family and "li" refers to orderly arrangement. So, literally, "Lunli" is the ordering of people from the elder generation to the younger generation, from the superior to the inferior, and therefore involves not only the objective relationship that has already been established but also a subjective understanding and adjustment of interpersonal relationships (Wang 2011, 2). In spite of the fact that both ethics and "Lunli" address the issue of humans, the former is aimed at eudaimonia, while the latter, harmony. Nevertheless, it should be noted that both eudaimonia and harmony are something long-term instead of short-term, ever-lasting rather than temporary.

A major contributor to the etymology of the word technē is William Jones, a British civil servant in the 19th century colonial India, who discovered the existence of a common Greek-Sanskrit stem, tekhn, meaning "woodwork" or "carpentry" (Mitcham 2009, 28). Roochnik quotes Kübe that "in its original form, technē probably means the building of a house which was woven together from trunks and twigs and was erected by the family or tribe in a communal effort" (Roochnik 1996, 19). With the development of division of labor, 
building houses becomes the expertise of the tektōn, the woodworker. Therefore, before the time of Homer, techne refers to the knowledge or skills of a carpenter. The reason why it's about woodworking instead of some other activity like smithing is that:

The activity of a carpenter is distinguished from that of the smith by its more rational character. It demands a capacity for intellectual solution of determinate tasks, some rudimentary knowledge of geometry or statics, in general, an ability to combine and improvise, which if explained to the layman is also sensible and comprehensible. (Roochnik 1996, 19)

It can be inferred from this explanation that technē is characterized by rational, precise, and communicable or teachable. Similarly, Taylor, in Routledge History of Philosophy, lists the standards of technē given by Thomas Brickhouse and Nicholas Smith as the rationality or regularity of some subject matter, knowledge, or wisdom, being teachable, learnable, determinate, free of mistakes, unique, and distinct (Taylor 2003, 382). These standards are corresponding to the definition given by Aristotle in Nichomachean Ethics, "a state of capacity to make, involving true reasoning" (Aristotle 2009, 105; 1140a, 10-11), because the equivalent Greek for "true reasoning" is logos, involving both reasoning and accounting, which implies knowledge and communicability.

The etymological explanations of those two concepts seem to be unable to intertwine them in any way. However, a close examination on technē in the works of Homer, Solon, and Aeschylus will reveal how technē has been mixed with ethics in ancient Greece.

\section{Original Unity of Technē and Ethics in Pre-Platonic Texts}

Generally speaking, Homer, Solon, and Aeschylus all use technē in the sense that it can serve some specific and definite purpose. As Felix Heinimann puts it, "each technē is correlated with a quite determinate task and type of achievement." Or, as Rudolf Lobl puts it, for every technē, "there is a telos, a goal, at which it aims... a kind of job or action, that has to be realized" (Angier 2010, 3).

To begin with, in Homer's epics, smithing and woodworking are considered as the paradigm of technē, as they are valuable to the community and the value of their products is tangible. For an example, in Iliad, Paris, acknowledging that Hektor rebukes him "right, not beyond measure, says, "still, your heart forever is weariless, like an axe-blade, driven by a man's strength through the timber, one who, with (technē), hews a piece for a ship" (Homer 1975, 3.60-63). It's obvious that the word here is used in its primitive sense of working on wood. Just like the shipbuilder who knows how to cut his wood at the right measure, Hektor's criticism hits the target as he rebukes his brother. Also, Homer writes in his Hymn to Hephaestus, "In earlier times (mortals) lived in caves on mountains like wild beasts, but now they have learned crafts (erga) because of Hephaestus, famed for skill (klutotechnēn), and thus all year long they pass their lives easily, without care in their own houses" (Gagarin \& Woodruff 1995, 35). It is communicating the information that technē has benefited man a lot to enable them to live a happy and prosperous life.

It is probably due to the close connection between technē and productive craft that this word is not used by Homer to refer to the prophet, doctor, singer, or herald, who are said to be the dēmiourgoi, those who work for the dēmos, the people, other than for themselves (Roochnik 1996, 24). However, things have changed in Homeric Hymns, where playing the lyre and the pipe is considered as a technē. Therefore, there is a tendency that dēmiourgos is going to be integrated into the rubric of technē (Roochnik 1996, 25). In other words, technē is aimed at the service of other people, just like what dēmiourgoi does. Therefore, the ethical dimension of 
technē is even more prominent, as it's aimed at contributing to the flourishing of others rather than that of the person who owns technē.

Roochnik observes that techneentes, one derivative of technē, is used to refer to the "artful" trap forged by Hephaestus to revenge Aphrodite and Ares (Roochnik 1996, 22), which might challenge the perfection of technē. This doubt may be cleared up when "art" and "artful" in English are taken into consideration. The fact that "artful" carries some derogatory meaning doesn't result in "art" doing the same. Therefore, it could be inferred from Iliad and Odyssey that technē, with its definite and specific purpose, is capable of leading man to happiness.

Based on Solon's texts, Roochnik renders that Solon's technē is value-neutral and cannot bring itself happiness, and that moira, and not technical expertise, brings evil and good to morals so as to determine their flourishing (Roochnik 1996, 31), a view that this paper is to argue against. Among the six technai mentioned by Solon, smithing, poetry, prophecy, farming, medicine, and fishing, the first three are considered as the gifts of gods according to Schaerer (Schaerer 1930, 2). It is obvious that gods send the mortals those technai as gifts for mortals' happiness or flourishing, probably from which Roochnik draws the above conclusion. However, in spite of the fact that gods send them those technai, it is the power of control offered by those technai themselves that make the mortals happy. Roochnik's second evidence of technē's neutrality is the word "useful," whose Greek equivalent is chrēstos, a verbal adjective derived from chraomai, "to use," and means not only "useful" but also "good" and therefore, "ethical value takes place within the realm of use" (Roochnik 1996, 31) instead of techne itself. The problem in this argument is that to say something that is useful or beneficial is not sufficient to infer that its value lies in its being used and the usefulness could be some potential in Aristotle's sense. Moreover, since something useful is also something good, technē is useful and good as well. As can be seen from the above analysis, technē in Solon's works is not value-neutral, but value-laden instead.

Finally, what Aeschylus shares with his predecessors is that technē is useful and good at once. In Prometheus Bound, before he gives the mortals the gifts of technē, Prometheus tells his audience, "Like shapes within a dream, (humans) dragged through their long lives and muddled all, haphazardly. They did not know how to build brick houses to face the sun, nor work in wood... They had no certain mark of winter nor of flowery spring or summer..." (Grene and Lattimore 1991, 448-86). He gives them such technai as building, medicine, agriculture, writing, animal husbandry, so that they will not swarm like bitty ants in dugouts in sunless cave, waste away, and will keep their memory of everything. But what differs him from his predecessors is that Aeschylus integrates arithmetic and writing into the category of technē, whose useful results are not so obvious and direct as other technai, but both of which function in an indirect way with their knowledge used to aid the process of production. Therefore, still, each of Aeschylus's technai has a definite and specific purpose from which humans benefit to a great extent.

The above text analysis may lead validly to the argument that the specific and definite purpose of technē is "good," as summarized by Aristotle in Nicomachean Ethics, "Every art (technē) and every inquiry, and similarly every action and choice, is thought to aim at some good; and for this reason the good has rightly been declared to be that at which all things aim" (Aristotle 2009, 3; 1094a, 1-2). For example, "the end of the medical art is health, that of shipbuilding a vessel, that of strategy victory, that of economics wealth" (Aristotle $2009,3 ; 1094 a, 8-10)$. Besides, it is evidently something of a truism in Greek that eudaimonia is the highest good for human beings. Hence, the conclusion of this part is that, according to Homer, Solon, and Aeschylus, technē is competent to play the role of guiding humans to the path of eudaimonia. 


\section{Technē and Technology}

"Technology" or its Greek equivalent "tekhnologia" consists of technē and logos, and hence means the logos of technē. Although there is no continuous usage in history that links "tekhnologia" to "technology," the term did appear in Latin with the meaning close to its root when French Protestant rhetorician Peter Ramus used technologia to refer to liberal arts and it didn't become strongly linked to modern industry until the beginning of the 19th century (Mitcham \& Schatzberg 2009, 35).

As technē develops into technology, the ethical part has fallen out, and as a result technology functions in a way totally different from technē. Both Heidegger and Carl Mitcham have explored the differences between technē and technology.

According to Heidegger, both technē and technology can reveal "being." But the former does it in the sense of bringing forth, a kind of nurture, aimed at the good, while the latter does it in the sense of challenging (Loscerbo 1981, 136). In other words, modern technology brings forth in order to sap energy from what is brought-forth or in order to use it as a resource in an endless chain of production. He says, "the revealing that rules in modern technology is a challenging, which puts to nature the unreasonable demand that it supplies energy which can be extracted and stored as such" (Heidegger 1977a, 327). In order to show the way modern technology essentially works, he takes a hydroelectric plant as an example,

The hydroelectric plant is set into the current of the Rhine. It sets the Rhine to supplying its hydraulic pressure, which then sets the turbines turning. This turning sets those machines in motion whose thrust sets going the electric current for which the long distance power station and its network of cables are set up to dispatch electricity. In the context of the interlocking processes pertaining to the orderly disposition of electrical energy, even the Rhine itself appears to be something at our command. (Heidegger 1977a, 321)

The Rhine revealed by modern technology serves as an energy source at men's command and even worse, the whole nature and man himself revealed by modern technology become what Heidegger calls "standing-reserve," taken advantage of technology by changing its natural telos. That's the reason why the essence of modern technology is Gestell.

Carl Mitcham by making a contrast between technē and modern technology concludes that the latter differs from the former in its pursuit for efficiency.

In ancient world, craftsmanship was dominant and men conducted technological activities in order to meet their simple, basic needs in life while in modern society, it is the engineering design that dominates and technological activities are targeted at satisfying men's ever increasing demands. Before the development of modern mechanic engineering and calculus, craftsmen have paid most of their attention to the form of their works, and their structural and aesthetic characteristics as the Greek believe beauty is good. But in modern society, people's attention is diverted to the efficiency of materials, energy, and space during the process of producing and making (Mitcham 2008, 338-9).

Whatever the difference is between technē and modern technology, it is something that dispels ethics in order not to let it get in the way of the endless development of modern technology. To Heidegger, it is the challenge upon nature and to Mitcham, it is the pursuit for efficiency. Highly developed as modern technology has become, its crashes with ethics are increasingly drastic and give rise to serious and alarming consequences for which men have to pay a huge price. 


\section{Conflicts between Technology and Ethics}

As indicated by Homer, Solon, and Aeschylus, the good of technē lies in its being able to preserve life and leads man to ever-lasting eudaimonia. However, technology seems to be going quite the opposite way by posing a tremendous threat against man's pursuit of the good. First of all, nuclear weapons have all along challenged man's survival. According to a report of DPA (Deutsche Presse Agentur) in 1983, the result of any atomic war, whatever level it is, is devastating - Man is going to disappear from the earth.

Secondly, with the power modern technology has given people in achieving almost everything, people fall lost in conquering nature, which in return, has reacted to man with revenge. The consumption of oil and coal by various industries has given rise to green house effect, the very reason for global warming. Meanwhile, some unrenewable resources are dwindling, and it's likely that we can leave our descendants nothing. The imbalance of the ecological system is an indirect threat to man's survival.

The last but not least, the threat of bio-tech is even more severe. Life becomes something that can be manipulated by technology, which thoroughly smashes man's respect for and the dignity of life. Aldous Huxley's Brave New World has depicted a picture in the future when bio-tech is highly developed. Every character in this book is "produced" instead of given birth to by human body. Being produced in the factory is considered natural and acceptable while being given birth to by a human body is shameful and humiliating, a sheer reversal of the original relationship between technology and natural course, by means of which ethics is reduced to nothing.

Many humanitarian philosophers of technology start to criticize modern technology in their own ways. Lewis Mumford, in Technics and Civilization, strongly criticizes monotechnic technology which exists only for its own sake and oppresses humanity as it moves along its own trajectory by advocating polytechnic one which enlists many different modes of technology, providing a complex framework to solve human problems. Also, Ortega argues that technology has concealed humans' ability to imagine, hope, and create as everything is fixed by technological experts. As a result, technology has become an empty form, unable to determine the content of life.

It's high time that some way should be worked out to get man out of this predicament and prevent technology from changing the world into that in Brave New World.

\section{The Way out of the Predicament}

The concept of techne in Homer, Solon, and Aeschylus may be of great help in this regard as the good that technē has embraced is aimed at preserving and promoting life. Although it's widely acknowledged that modern technology has been poles apart from technē, but this ethical dimension of technē is still applicable to modern technology, as long as human nature remains the same as before and technology is still what has been invented by man. It's impossible for modern technology to go back to become technē again, but if technological activities are aimed at man's eudaimonia, most negative influences could be avoided.

Following this idea, Erich Fromm suggests some specific steps in the establishment of humanized technology.

A. Planning which includes the system Man and which is based on norms which follow from the examination of the optimal functioning of the human being.

B. Activation of the individual by methods of grassroots activity and responsibility, by changing the 
present methods of alienated bureaucracy into one of humanistic management.

C. Changing of the consumption pattern in the direction of consumption that contributes to activation and discourages passivation.

D. The emergence of new forms of psychospiritual orientation and devotion, which are equivalents of the religious systems of the past (Fromm 1968, 64).

Apparently, all those humane steps are to serve the purpose of promoting life.

Similar to Fromm, Heidegger's way out of this difficult situation is to turn to art to cope with the negative effects of modern technology. According to him, art, which is fundamentally poetry, discloses "being" and is the highest form of production, and the highest form of technē. He offers an example to illustrate his point:

What does the technological outlook see in trees? It sees disposables: lumber, cellulose, marketable fruit, a tourist attraction, etc. Technology then sets out to turn the trees into actual disposables. What does the poet see in trees? The poet does not see anything beyond or different from lumber and the rest. What then distinguishes a poem from a logging prospectus is that the poem purposely disregards the lumber... What the poem holds up to our view is the tree-however understood - in the mystery of its emergence into existence. (Rojcewicz 2006, 204)

The first way of looking at trees is obviously instrumental, taking them as means, while the second poetic way takes those trees as end, a prerequisite for achieving the good.

Both Fromm and Heidegger are trying to recover the ethical element of techne to solve the problems brought about by modern technology for the sake of man's eudaimonia instead of temporary pleasure. However, in this process of integrating ethics with technology, it should be avoided that technological development will give up to ethical values whenever and wherever possible. As to the establishment of the proper relationship between technology and ethics, traditional Chinese ethics may help a lot with its emphasis on "harmony." Just like the two forces of "yin" and "yang," ethics and technology can complement each other to form a complete and harmonious whole. In this case, a harmony will subsequently occur between man and himself, man and nature, man and the society.

\section{Conclusion}

Hans Jonas, in 1979, observes that the nature of community activities has changed in modern society and therefore, since the traditional ethics takes man as its object, it is no longer applicable to the new situation nowadays. Jonas does notice the ecological destruction brought about by modern technology, but it is not the result of a completely new activity, and human's activities haven't gone through that drastic change as indicated by Jonas. Besides, the traditional ethical values should serve as the root instead of the nuisance of modern society, and they should be working today and will work as well in the future. There lies in technē a call for modern technology to return its homeland of unity with ethics, so as to save human beings from the current moral crisis and lead them to eudaimonia. In modern society, technology has satisfied man's demands for various pleasures, which are only temporary and transient, and deceived man that it has brought them happiness and flourishing. And shortly after that, the temporary pleasures will be replaced by endless agony, pain, and torture, namely environmental pollution, ecological imbalance, etc. In order to cope with those problems, modern technology should, as technē does in the three pre-platonic writers, start from the good and arrive at man's eudaimonia, everlasting and sustaining so as to preserve and improve life. 


\section{Works Cited}

Angier, Tom. Technē in Aristotle's Ethics. London/New York: Continnum, 2010.

Aristotle. The Nicomachean Ethics. Trans. David Ross. Oxford: Oxford University Press, 2009.

Bambach, Charles. Heidegger's Root-Nietzsche, National Socialism and Greek. Shanghai: Shanghai Bookstore Publishing House, 2007.

Bunnin, Nicolas, and Yu Jiyuan. Dictionary of Western Philosophy. Beijing: People's Publishing House, 2001.

Giddens, Anthony. The Consequences of Modernity. Shanghai: Yilin Publishing House, 2000.

Fromm, Erich. The Revolution of Hope. New York: Harper \& Row, 1968.

Gagarin, Michael, and Paul Woodruff. Early Greek Political thought from Homer to the Sophists. Cambridge: Cambridge University Press, 1995.

Grene, David, and Richmand Lattimore. Greek Tragedies, Vol. 1. Chicago: University of Chicago Press, 1991.

Hegel, Georg. Elements of the Philosophy of Right. Beijing: The Commercial Press, 1961.

Heidegger, Martin. “The Question Concerning Technology.” Basic Writings. Ed. David Farrell Krell. New York: Harper \& Row, 1977. 311-41.

Homer. Iliad. Trans. Richmand Lattimore. New York: Harper \& Row, 1975.

Lin, Dehong. Man and Machine - the Essence of High-Tech and Recover of Humanism. Nanjing: Jiangsu Education Publishing House, 1999.

Loscerbo, John. Being and Technology - A Study in the Philosophy of Martin Heidegger. Hague/Boston/London: Martinus Nijhoff Publishers, 1981.

Mitcham, Carl. Thinking through Technology — the Path between Engineering and Philosophy. Shenyang: Liaoning People's Publishing House, 2008.

Mitcham, Carl, and Eric Schatzberg. "Defining Technology and the Engineering Sciences." Philosophy of Technology and Engineering Sciences. Ed. Anthonie Meijers. Amsterdam: Elsevier, 2009. 27-64.

Roochnik, David. Of Art and Wisdom: Plato's Understanding of Techne. University Park: The Pennsylvania State University Press, 1996.

Rojcewicz, Richard. The Gods and Technology. Albany: State University of New York Press, 2006.

Schaerer, René. Episteme et Techne: Studies on the Notions of Cognition and Art from Homer to Plato. Macon: Protat Frères, 1930.

Taylor, C. C. W. Routledge History of Philosophy: from Beginning to Plato. Beijing: China Renmin University Press, 2003.

Wang, Qian. Introduction to Technological Ethics. Beijing: China Renmin University Press, 2011. 